\title{
Can Ethics And Strategy Co-Exist: A Human Resource Management Case Study
}

Arthur K. Fischer, (E-mail: afischer@pittstate.edu), Pittsburg State University Mallory Murray, (E-mail: mallorym@gmail.com), Pittsburg State University

\begin{abstract}
An HRM case dealing with problems encountered as ethics conflict with strategy. Discussion concerns how such a case can be used to exhibit the alignment between HRM and business strategy.
\end{abstract}

\section{INTRODUCTION}

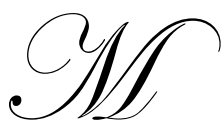

idwest Education, Inc. is a major supplier of educational materials for the United States. The company focus is on learning tools and systems for use in technology, science and business classrooms. In addition, it develops and provides books, manuals, videos, software and hardware used in the fields of technology education, instructional development and business applications.

The company has its headquarters and primary manufacturing plant in a major Midwest community. In addition, the Creative Development offices are located in Massachusetts and California. Transportation, Service and Maintenance facilities are headquartered out of Texas, with major branches in Baltimore and Phoenix.

The three main divisions exemplify three different strategies: cost-reduction, quality enhancement, and innovation (as discussed by Schuler and Jackson, 1987).

\section{Transportation, Service And Maintenance}

The primary strategy of the Transportation, Service and Maintenance Division is cost-reduction. Midwest Education, Inc. has long been known for providing service and maintenance programs which are very reasonably priced.

\section{Manufacturing}

The primary strategy of the Manufacturing Division is quality enhancement. Midwest education, Inc. has an enviable history of providing the highest quality products which have been adopted by first-rate schools and corporate training programs.

\section{Creative Development}

The primary strategy of the Creative Development Division is innovation. Midwest Education, Inc. is widely known for providing truly cutting edge teaching materials which always mirror the latest techniques and processes.

Various HRM problems occur at these different facilities. These problems require students to develop responses and show how their responses can support the overall strategic plans of the division involved. 


\section{COMPANY HISTORY}

Midwest Education was started by Henry and Mary Dalton in 1975. Dr. Henry Dalton was an industrial arts teacher before he got his MBA and went on to get his Ph.D. in Technology Education. Mary was a software developer who also taught business seminars. At that time a new wave of emerging technology was beginning to alter the way people learn and communicate. By developing Midwest Education, Inc. the Daltons began work in an exciting new field. They found a vast market for quality tools that educated people on how to use all the new technology. Dr. and Mrs. Dalton are in semi-retirement now and travel extensively, but remain major shareholders in the business. They personally hired the CEO when they went into semi-retirement.

The company started with about fifty employees, but has grown consistently and now has a total of 416 employees within its three major divisions: 158 employees work in the Manufacturing Division, 123 work in the Creative Development Division and 135 work in the Transportation, Service and Maintenance Division. There are also 71 employees working at the headquarters in Kansas City (including the corporate staff).

At the beginning on the 1990s it became apparent that international business was becoming the rule rather than the exception. The company went international in 1994 and now is exporting to three European, two Latin American, and two Pacific Rim countries. The Global Operations Division is located within the headquarters.

\section{Headquarters}

The corporate headquarters are in Kansas City. The CEO of Midwest Education, Inc. is Judith Lund. Ms Lund was hired by the Daltons in 1994 when they decided to take a less active role in the company while remaining major shareholders. Ms. Lund has an MBA in business management, and was previously the CEO of a small telecommunications company. In her previous position, Ms Lund had successfully steered the company out of financial difficulties by raising stock value. She had initiated a strong advertising campaign and had put the company 'in the black' for the first time in seven years.

The COO of Midwest Education, Inc. is Frank Rose. Frank has been with the company since 1989. Mr. Rose, a cousin of Dr. Dalton, had a successful career with an international business training group in California. His desire to move back to his home town of Kansas City came at a time when the Daltons were looking for a COO. He has worked out well for the company.

The Human Resources Department is also located at the headquarters. The Vice President for Human Resources is Lawrence Wilson. Mr. Wilson has a degree in industrial and organizational psychology and an MBA. He has been with the company for 11 years. He started out as a generalist and was promoted as he showed good judgment with hiring and earned his MBA at the same time.

Within the Human Resources Department there are four sections:

1. Staffing, the head of this section is Patrick Shew.

2. Compensation and benefits section, headed by Michael Martin.

3. Labor management relations section, headed by Keith Lane.

4. Training, career development and performance appraisal section, headed by Cynthia Burns.

There are also human resource specialists in each of the three divisions around the country.

\section{Manufacturing Division}

The mission statement for the Manufacturing Division is:

"The aim of the Manufacturing Division of Midwest Education, Inc. is to continually improve the quality and strength of all our products. The superior products for which we have become world renowned will still be 
manufactured along with new and innovative products and ideas. We will work hard to keep quality high and cost down while supplying customers with the best possible products in the shortest possible time." The Manufacturing Division follows a strategy of quality enhancement.

The main manufacturing plant is located on the outskirts of Kansas City, not far from the company headquarters. The president of the Manufacturing Division is Max Thorn. Mr. Thorn has been with the company almost since its inception. He was one of the first employees hired by the Daltons. He started writing programs for the company and originally worked alongside the Daltons in interviewing and hiring many other employees.

The head of human resources for the Manufacturing Division is Janine Woods. She has a staff of five generalists who assist her in meeting HRM needs for the Manufacturing Division.

The Manufacturing Division used to be housed in the same building as the headquarters. As the business expanded and more room was needed, the division moved to the suburbs into a large factory site. There are 158 employees in the Manufacturing Division. They are divided into ten teams, each team works at producing and packaging a specific product at a time. There are five supervisors who each supervise two teams: Doris Malone, John Fizer, Sandi Cross, Wendy Atchison, and Ian Carpenter.

The Manufacturing Division usually has a long lead time on orders and can anticipate what will be needed. The factory has flexible work areas that can be re-tooled and rearranged for the changeover from one product to another in less than four hours. The pay in this Division starts at $\$ 6.25 / \mathrm{hr}$ for production workers and has a full benefits package. Most employees seem happy with their work. Max Thorn is generally thought of as a good, easy-going man to work for.

\section{Creative Development Division}

The mission statement for the Creative Development Division is:

"In the Creative Development Division of Midwest Education, Inc. we will strive to bring our customers the most innovative and cutting edge programs and products in the world. Our team of creative professionals is constantly working to improve, upgrade, and create the most useful products to bring to our customers." This division follows a strategy of innovation.

The Creative Development Division has two locations; a headquarters in California and a branch located in Massachusetts. The president of the Creative Development Division is Serena Tibaldo. Ms. Tibaldo recently joined the company. Previously she was a software developer for a large computer game producer. She has a bachelor's degree in business and a computer programming master's degree, and is doing very well at Midwest.

The head of human resources for the Creative Development Division is Amelia Chi, who is located at the California headquarters. Ms. Chi has a staff of five assistants. The head of the human resource section at the Massachusetts branch is Virginia Fox. Ms Fox has a staff of two assistants.

There are 90 people employed at the California plant and 38 at the Massachusetts location. The California location opened in 1980 and the Massachusetts branch was opened in 1993. In the 1970's and 1980's many computer software programmers moved to the west coast to be located in Silicon Valley. Most people hired by Midwest Education, Inc. transferred from wherever they lived to the Ca1ifornia branch, with the company paying all relocation expenses. By 1990 some employees desired to live in the east. The Daltons decided it was time to expand the company and in doing so decided the next branch would be in the Massachusetts area. Most of the long time elected to remain California. The majority of recent hires are in Massachusetts. 


\section{Transportation, Service And Maintenance Division}

The mission statement for the Transportation, Service and Maintenance Division is:

"The Transportation, Service, and Maintenance Division is committed to providing the fastest and most cost effective way of safely shipping our product to our customers. No effort will be spared as we streamline and improve our fast and friendly service". The Transportation, Service and Maintenance Division follows a strategy of cost-reduction.

The Transportation, Service and Maintenance Division headquarters is located in San Antonio, Texas. There are major branches in Baltimore, Maryland and Phoenix, Arizona. The President of the Transportation, Service and Maintenance Division is Mark Derrick. Mr. Derrick is based in San Antonio. Mr. Derrick has been with Midwest Education, Inc. for 13 years. He personally hires the managers for the other branches in Maryland and Arizona.

The head of human resources for the Transportation, Service and Maintenance Division is Salvador Vasquez. Mr. Vasquez has a staff of five assistants. Mr. Vasquez appoints HR heads to the other branches. Often they are employees from San Antonio that he knows well and trusts.

The Transportation, Service and Maintenance Division was originally based in Kansas City. As the company grew a decision was made to relocate the division to Texas. The other branches are newer, with Maryland opening in 1989 and Arizona in 1996. There are 55 employees in San Antonio, and 40 in each of the other two branches.

\section{SITUATION}

Midwest Education has been struggling financially for the past two years. The members of the Executive Committee (CEO, COO, and division presidents) have made many changes over the past two years to try to correct the deteriorating financial situation, but the poor economy has caused many states to cut their education budgets. High quality teaching tools, such as those provided by Midwest Education, have taken the brunt of many such cuts.

Judith Lund, Frank Rose and Lawrence Wilson have examined this situation carefully, and have now decided it is necessary to cut back on the payroll. In order to discuss this issue and how to go about deciding whom to layoff, they have called a meeting with the presidents and HR directors of the company's three divisions.

Frank Rose: As you all know, our company has been going through some difficult times recently. Our profits (and stock prices) are down, while our expenditures are up. We have tried a variety of measures at Headquarters to avoid ending up in this situation, but unfortunately they have not been as successful as we need. We're now in the position where we have to cut expenditures significantly within the next month in order to finish the fiscal year close to the budget and appease the stockholders.

It is my deepest regret to inform you that we called you here today to tell you that we need to cut payroll expenses by at least ten percent. We hope that this will be a temporary cut, and that no further cuts will be required, but we can’t promise that.

As you know, we have always greatly valued our employees and have striven to be a good company to work for, so you can understand why this is a very difficult situation for us. Because of the delicate nature of this task we would like to present a unified front for the layoffs to ensure that they are handled as fairly as possible.

We are thinking that the best and fairest way to handle the layoffs would be to target the least senior workers within each division, making sure that each division has a ten percent cut in workers. What we are hoping to receive from you today is feedback on any problems you foresee. I hope we can have an honest discussion here and come to a satisfactory position for all divisions and for the company as a whole. We need to be as fair as we can while still meeting the ten percent layoff constraint, and we have to assure that we handle this situation as efficiently as possible. Are there any suggestions? 
Max Thorn (President, Manufacturing): I'm not sure I agree with having only one policy. I think the number one thing we need to be concerned about is the quality of the remaining employees. Obviously, the only fair thing to do would be to do an evaluation of every employee and decide who to terminate based on who is most valuable to the company.

Salvador Vasquez (HR, Transportation, Service and Maintenance): I agree with Max. However, my concern would be with conducting an entire employee review in a month, and doing a fair and accurate job. This is a large task, and there's only a short amount of time to accomplish it. While it seems the most fair, I also think we'll lose a lot of productivity during that month because people will be so worried about their reviews and the upcoming terminations that they won't be able to concentrate.

Mark Derrick (President, Transportation, Service and Maintenance Division): A review like that seems costly to me. I think we should just terminate the highest paid employees until we get to the amount of money we need to save, no questions asked. It would result in fewer terminations, so we wouldn't be as behind on staffing and would save money quickly. We would only have to terminate less than six percent of workers, which for our department of 135 is eight workers. I'd rather terminate eight workers than thirteen, which we could do if we chose only the highest paid workers.

James Woods (HR, Manufacturing): I think this is a good idea, but looking beyond the numbers I have a concern. Our highest paid employees are also our oldest employees. In fact, on average many of the highest paid employees will retire within five years. While there may be no legal problems with this, it seems like bad policy to terminate dedicated employees right before they could fully retire. However, I do agree with the cost effectiveness of the plan. On the other hand, if we had to offer them a buyout the monetary benefits would be greatly reduced.

Serena Tibaldo (President, Creative Development): Our department recently sent a group of employees to an expensive but amazing conference in New York City. They've really learned a lot that they've brought back to the company. Some in this group are senior employees who have inspired great new ideas. It sometimes seems that we rely on new (and younger) employees to come up with the newest ideas, but I don't always see the newer, younger employees making the necessary connections to our product line. It may be due to the newer employees' lack of experience that's holding them back some, but if we do terminate only the most senior or the highest paid workers I'd want to make sure that the most creative of my more experienced employees were protected. If we followed Mark's plan, we might have to lose many of our most highly experienced employees, and this could be disastrous.

Amelia Chi (HR, Creative Development): I agree, we'd much rather get rid of a few of the lower paid employees who aren't coming up with new ideas and applications than get rid of the higher paid employees who are familiar with the product line.

Mark Derrick: I worry about getting rid of the lowest paid employees because in our department those would be our new hires. Many of our new hires are women and minorities we brought in to meet our affirmative action plan. If we get rid of the newest employees we could be facing legal problems again.

James Woods: I can't help but worry about how quality will suffer if we go for either of the other departments' plans. We can't afford to get rid of our best workers who may be our highest paid, but on the other hand we certainly can't operate if we have to get rid of such a large quantity of lower paid employees. We won't be able to operate well if we lose our best employees or if we lose a larger chunk of marginal employees. And is it good for our public relations if we get rid of all of the lowest paid employees and put such a large number of employees out of work, just so we could keep a few senior employees? For some of us that could be a big, negative recruiting factor in our communities. Neither option seems like a good way to treat people or a good deciding factor for terminating someone. Maybe it would be better if each department could handle their own terminations by selective cutting.

Judith Lund: Letting each department handle its own layoffs would be an equity nightmare because there would be little control over the departments, and I fear that someone would say that favoritism came into play. From a public relations perspective, it is much easier to come up with a reason and a stance for one choice, such as seniority, 
than to try and defend different decisions made for different reasons.

Lawrence Wilson: Headquarters would like to keep a close eye on how layoffs are handled. While we trust all of you to do a good job, this is an enormous task and one that will certainly draw some media scrutiny. It's imperative that everything be handled in a single, defensible manner.

Amelia Chi: It just seems to me that every department should be allowed to operate its own terminations.

Judith Lund: Obviously, there's a lot to consider here. I worry more about the consistency of our plan and how it will be reported in the media if we don't have a single policy for all the divisions. Let's adjourn the meeting for now. I guess I'll have to make a final decision, and we'll have a meeting in two days to inform you of the final decision and to consider how to go about implementing the process. I thank you all for being here, and appreciate all of your inputs. I promise you we will carefully consider them, and that our company, as always, is concerned with making the best choices for everyone involved.

\section{DISCUSSION QUESTIONS}

1. How will having one, company-wide policy affect each department's adherence to its strategy? Would it be better to have a different company-wide policy, or let each division choose its own termination method?

2. What are the ethical concerns of a single, company-wide policy? Do any of the other suggestions that were offered seem more ethical?

3. If you were the $\mathrm{CEO}$ or $\mathrm{COO}$, what would you decide? Why? What problems would this entail?

\section{LEADER'S QUESTIONS}

1. What should you consider when trying to decide which option to choose?

2. How do you weigh ethical questions such as whether or not to put people close to retirement out of a job, but only a few of them, or whether to put a larger amount of new hires out of a job?

3. What should you consider when trying to decide between a company-wide policy or three different policies?

4. Are there options the company hasn't considered? What would be the ethical considerations with each option? (Examples might include: reducing the work hours and/or pay by 10 percent company-wide; offering a severance package or optional early retirement to volunteers; letting employees help make the decision, and so forth.)

5. What could the company do to soften the impact of the terminations, to encourage better public relations, or to keep terminated workers as potential future employees?

\section{REFERENCE}

1. R.S. Schuler and S.E. Jackson, Linking competitive Strategy with Human Resources Management Practices, Academy of Management Executives, 1 (August, 1987), p.213. 